\title{
Boty-II, a novel LTR retrotransposon in Botrytis cinerea B05.10 revealed by genomic sequence
}

\author{
Ming Zhao \\ Chengdu Institute of Biology \\ Chinese Academy of Sciences \\ Chengdu 610041, PR China \\ Graduate University of Chinese Academy of Sciences \\ Beijing PR, China \\ Jin yan Zhou \\ Chengdu Institute of Biology \\ Chinese Academy of Sciences \\ Chengdu 610041, PR China

\section{Zhi dong Li} \\ Chengdu Institute of Biology \\ Chinese Academy of Sciences \\ Chengdu 610041, PR China \\ Wei wei Song \\ Chengdu Institute of Biology \\ Chinese Academy of Sciences \\ Chengdu 610041, PR China \\ Graduate University of Chinese Academy of Sciences \\ Beijing 100039, China

\section{You jiu Tan} \\ Chengdu Institute of Biology \\ Chinese Academy of Sciences \\ Chengdu 610041, PR China \\ Graduate University of Chinese Academy of Sciences \\ Beijing 100039, China

\section{Hong Tan*} \\ Chengdu Institute of Biology \\ Chinese Academy of Sciences \\ Chengdu 610041, PR China \\ Tel: 8602885219314 \\ Fax: 8602885219314 \\ E-mail: abath@cib.ac.cn
}

Financial support: Key Project of Chinese Academy of Sciences (No.KSCX2-YW-G016), (No.KSCW2-YW-N-007) and the Hi-Tech Research and Development Program (863) of China (No.2006AA10A213).

Keywords: Botrytis cinerea, LTR retrotransposons, molecular marker, plant pathogen, population diversity, transposable elements.

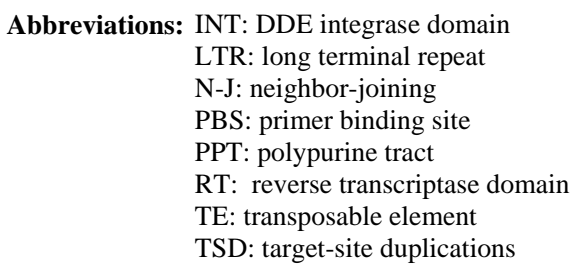

Botrytis cinerea is a necrotrophic pathogen causing preand post-harvest diseases in at least 235 plant species. It manifests extraordinary genotype and phenotype variation. One of the causes of this variation is transposable elements. Two transposable elements have been discovered in this fungus, the retrotransposon (Boty), and the transposon (Flipper). In this work, two complete (Boty-II-76 and Boty-II-103) and two partial

*Corresponding author 
(Boty-II-95 and Boty-II-141) long terminal repeat (LTR) retrotransposons were identified by an in silico genomic sequence analysis. Boty-II-76 and Boty-II-103 contain 6439 bp nucleotides with a pair of LTRs at both ends, and an internal deduced pol gene encoding a polyprotein with reverse transcriptase and DDE integrase domains. They are flanked by 5 bp direct repeats (ACCAT, CTTTC). In Boty-II-141, two LTRs at both ends, and a partial internal pol gene encoding a protein with a DDE integrase domain were identified. In Boty-II-95, a right LTR and a partial internal pol gene encoding a protein with no conserved domains were identified. Boty-II uses a self-priming mechanism to initiate synthesis of reverse transcripts. The sequence of the presumed primer binding site for first-strand reverse transcription is 5'-TTGTACCAT-3'. The polypurine-rich sequence for plus-strand DNA synthesis is 5'-GCCTTGAGCGGGGGGTAC-3'. Fourteen BotyII LTRs that contain 125-158 bp nucleotides and share $69.1 \sim 100 \%$ identities with the short inverted terminal repeats of 5 bp (TGTCA...TGACA) were discovered. Analysis of structural features and phylogeny revealed that Boty-II is a novel LTR retrotransposon. It could potentially be used as a novel molecular marker for the investigation of genetic variation in B. cinerea.

Botrytis cinerea Pers. Fr. (teleomorph Botryotinia fuckeliana (de Bary) Whetzel), the cause of grey mould, is a necrotrophic pathogen causing pre- and post-harvest diseases in at least 235 plant species. It is an important pathogen of nursery plants, vegetables and ornamentals, as well as field and orchard crops, and stored and transported agricultural products (Elad et al. 2007). World wide losses from this fungus account for $20 \%$ of the harvest of the affected crops, and their cost is estimated at 10-100 billion euros per year (Genoscope, 2008). The market size for antiBotrytis products has been 15-25 million US dollars in recent years (Elad et al. 2007).

B. cinerea has a reputation for unusual genetic diversity and morphological variability, since $B$. cinerea isolates have morphologically distinct cultural types and have a tendency to change constantly during successive generations in vitro or under field conditions. Subcultures from single conidia often differ in morphotype from the parents and from each other. The genotypic and phenotypic variation is thought to be important to the changes in populations that occur in response to the broad host plants and fungicides. Development of resistance to fungicides has been recorded in Botrytis populations throughout the history of the modern fungicide era (Beever and Weeds, 2007; Elad et al. 2007). The causes of the genotypic and phenotypic variation are thought to be sexual reproduction, heterokaryosis, aneuploidy and extrachromosomal elements like mitochondria, viruses, plasmids and transposable elements (Beever and Weeds, 2007).

Transposable elements (TEs) are mobile, repetitive DNA sequences of genomes that can alter the sequence, expression and chromosome rearrangements of genes. These changes have the potential to cause wide-ranging genetic variation, giving populations the flexibility to adapt successfully to environmental conditions, particularly in species that do not have a sexual phase (de Lima Fávaro et al. 2005). TEs are grouped into two classes by their transposition intermediate: RNA (class I or retrotransposons) or DNA (class II or DNA transposons) (Wicker et al. 2007). In B. cinerea, two TEs have been found: a retrotransposon (Boty), and a transposon (Flipper) (Diolez et al. 1995; Levis et al. 1997). Boty contains 596 bp long terminal repeats (LTR) and one internal putative gagpol gene that encodes a polyprotein with sequences homologous to the reverse transcriptase (RT) and RNase $\mathrm{H}$ (RH) domains of retroelement pol genes (Diolez et al. 1995). Flipper is 1842 bp long with perfect inverted terminal repeats of $48 \mathrm{bp}$ and an open reading frame (ORF) encoding a transposase (Levis et al. 1997). The two TEs are important and useful molecular markers for the investigation of genetic diversity in $B$. cinerea. Based on the presence or absence of Boty and Flipper, isolates having both Tes (transposa), isolates without TE(vacuma), isolates only containing Boty, and isolates only containing Flipper were identified (Giraud et al. 1997; Giraud et al. 1999; Muñoz et al. 2002; Ahmed and Hamada, 2005; Ma and Michailides, 2005; Milicevic et al. 2006; Kretschmer and Hahn, 2008).

The $4.5 \mathrm{x}$ whole genome shotgun (WGS) sequences of $B$. cinerea strain B05.10 are publicly available (Billault et al. 2006). In this work, a LTR retrotransposon designated Boty-II was identified by in silico genomic sequence analysis. Its structural characteristics, including its short inverted terminal repeats, the length of its LTRs, and its primer binding site (PBS) and polypurine tract (PPT) sequences revealed that Boty-II is a novel LTR retrotransposon. This was validated by phylogenetic analyses based on LTR DNA sequence and RT domain amino acid sequences. Boty-II potentially provides a molecular marker for surveying the genetic diversity of $B$. cineria.

\section{METHODS}

\section{Boty-like element analysis}

The DNA sequence of the Boty LTR (GenBank Accession no: $\underline{\mathbf{X 8 1 7 9 0}}$ ) and internal gag-pol gene (GenBank Accession no: $\underline{\mathbf{X 8 1 7 9 1}}$, (Diolez et al. 1995)) were obtained from GenBank, and were used to query the genome database of B. cinerea B05.10 by Blastn search provided by the Broad Institute, (Altschul et al. 1997). All Blast hits of $\mathrm{E}$ value $<10^{-4}$ were extracted using Browse Region provided by the Broad Institute. Blast hits flanked by a pair of Boty LTRs were considered Boty retrotransposons. Blast hits not flanked by Boty LTRs are potentially the gag-pol genes of novel retrotransposons. 

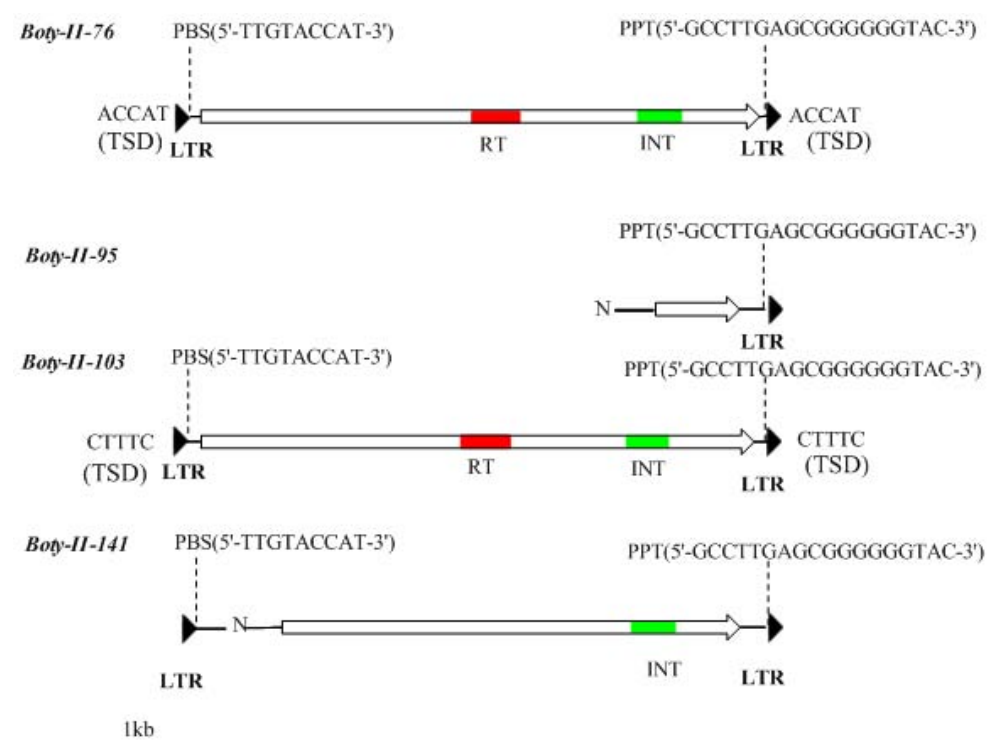

Figure 1. Diagram of Boty-II. DNA is depicted by $\_$, Putative genes are depicted with the $\square$, LTRs are indicated with - , the putative reverse transcriptase domain (RT) is indicated with $\mathbf{v}$, the putative DDE integrase (INT) domain is indicated with indicates gaps in the genomic sequence.

\section{Novel LTR retrotransposon identification}

To identify putative novel retrotransposons, we performed in silico chromosome walking in both directions on Blast hits not flanked by Boty LTRs. Approximately $1 \mathrm{~kb}$ up- and downstream of each Blast hit was extracted using Browse Region. The up- and downstream extracts of each Blast hit were aligned by bl2seq (http://www.ncbi.nlm.nih.gov/Blast/bl2seq/wBlast2.cgi), (Tatusova and Madden, 1999). The termini of alignments were analyzed by manual inspection. Elements flanked by short inverted terminal repeats, with high sequence similarities, were considered novel LTRs. Elements flanked by a pair of novel LTRs and containing internal deduced gag-pol gene were considered novel retrotransposons and designated as Boty-II.

Sequences of Saccharomyces cerevisiae tRNAs used for identification of PBS were obtained from the Genomic tRNA Database (Lowe and Eddy, 1997). The PPT and the target-site duplications (TSD) of LTR retrotransposon were investigated by manual inspection.

\section{Distribution of Boty-II like elements}

To identify the distribution of the Boty-II elements, the DNA sequence of one Boty-II was extracted using Browse Region, and used to query the $B$. cinerea B05.10 genome. All Blast hits were extracted and analyzed by manual inspection. Elements were designated Boty-II-xx, where xx is the supercontig number in which the Boty-II was detected. LTRs were designated Boty-II-xx L (R). Solo LTRs were named $S$-II-xx. For example, a novel LTR retrotransposon in the supercontig 76 was designated as
Boty-II-76, and the left (right) LTR of Boty-II-76 was named Boty-II-76- L (R).

\section{Phylogenetic analyses}

To verify Boty-II as a novel LTR retrotransposon, two phylogenetic analyses were developed. One was based on the nucleotide sequences of Boty-II and Boty LTRs, the other on the deduced amino acid sequences for the RT domains of Boty-II and Boty. Multiple alignments of protein or DNA sequences were created by MEGA version 4 (Tamura et al. 2007). Phylogenetic trees were constructed based on the alignment by MEGA version 4 using the neighbor-joining (N-J) method (Saitou and Nei, 1987). The tree was subjected to bootstrap resampling of 1000 replicates. Default parameters were accepted for all programs.

\section{RESULTS AND DISCUSSION}

\section{Novel LTR retrotransposons in the genome of $B$. cinerea B05.10}

Using the Boty LTR and internal pol gene sequence as queries, 27 putative gag-pol genes were identified and 23 of them were flanked by Boty-like LTRs. Four genes showed homology to the gag-pol retrotransposon gene, and were not flanked by Boty LTRs, indicating novel LTRs retrotransposons in B. cinerea B05.10 genome. We performed in silico chromosome walking in both directions on Blast hits that were not flanked by Boty LTRs. Approximately $1 \mathrm{~kb}$ up- and downstream of each Blast hit was extracted, and aligned by bl2seq. A novel type of LTR, designated Boty-II LTR, was identified. Elements that contained putative internal gag-pol genes and were flanked 
a TGT CACGGCGCCAACTA CATGTTCTGTAGTTGCCTTCGTG CCTTAGGCACGGACTACTAGCGTGCCCTGCTTCCTATAAG TA GGGCC TCACTC TTCCATAGCTCT TCCACCCTTATGGTA CAATATACGTCTTTACCCGTGCCTTGACAGTTTGTACCAT CTTC

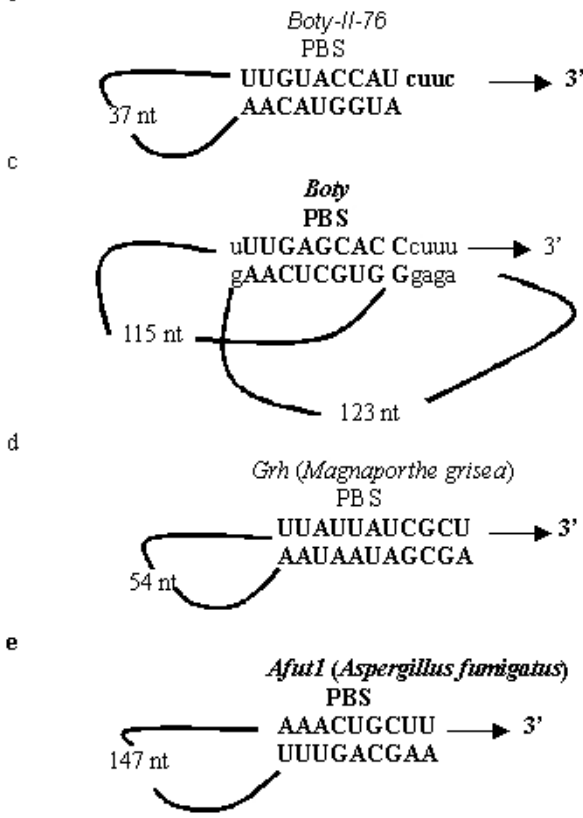

Figure 2. a DNA sequences of Boty-II- 76 left LTR and PBS. Short inverted terminal repeats are indicated in red, the PBS and nucleotides complementary to LTR are underlined; b, c, d, e Putative RNA structures of Boty-II-76, Boty, Grh and Afut1. The names of TR-retrotransposons and host organisims are listed on the top of each structure. The position of the PBS is indicated by capitalization. The GenBank Accession numbers of retrotransposons used in the sequence analysis are Afut1, L76086; Boty, X 81790 and Grh, M77661. c, d, e is from Lin and Levin (1997).

by Boty-II LTRs represented novel LTR retrotransposons and were designated Boty-II.

\section{Structural characteristics of Boty-II}

Four Boty-II retrotransposons were identified and designated Boty-II-76, Boty-II-95, Boty-II-103 and Boty-II141. Boty-II-76 and Boty-II-103 are flanked by 5 bp direct repeats (ACCAT, CTTTC) representing TSD. Both contain 6439 bp nucleotides, and share $99.7 \%$ identity. They contain an internal deduced pol gene encoding for a polyprotein with RT and DDE integrase (INT) domains (Figure 1, Table 1). Each element contains an identical LTR at both ends. The LTRs of Boty-II-76 and Boty-II-103 share $99.3 \%$ identity, with one site mutation. Because of gaps in the genome, only partial sequences of Boty-II-95 (149 bp right LTR and a partial internal pol gene encoding for a protein without conserved domains) and Boty-II-141 (two LTRs sharing 149 bp, with 96.6\% identity and a partial internal pol gene encoding for a protein with an INT domain) were identified (Figure 1, Table 1). The fact that the domains of Boty-II within the pol gene are arranged in the order RT and INT revealed that Boty-II belonged to the Ty3/gypsy group of retrotransposons.

Most LTR retrotransposons have a region adjacent $t$ to the left LTR known as the minus-strand PBS, which is complementary to the 3' end of this tRNA (Kordiš, 2005). We screened the PBSs of Boty-II using the sequences of $S$. cerevisiae tRNAs, and no complementarity to any $S$. cerevisiae tRNAs or to the highly conserved CCA sequence found at the 3'end of all tRNAs was detected (Kordiš, 2005). This indicated that Boty-II potentially uses a selfpriming mechanism to initiate synthesis of reverse transcripts. We found that Boty-II-76, Boty-II-103 and Boty-II-141 contain the identical PBSs for first-strand reverse transcription with 9 nt (5'-TTGTACCAT-3') immediately downstream of the left LTR that are complementary to the $9 \mathrm{nt}$ nucleotides of the LTR (Figure 2a, Figure 2b). Many Tf1 elements, including Tf1, Tf2, MAGGY, Skipy, Grh, Afut1, CfT1 and Boty are able to "selfprime” reverse transcription (Levin, 1995; Levin, 1996; Lin and Levin, 1997; Butler et al. 2001). This work revealed that Boty-II belongs to the Tf1 group. Though Boty and Boty-II may both be able to "self-prime" reverse transcription, the PBSs of Boty-II and Boty are different. According Lin and Levin (1997), the PBS of Boty can potentially form extended RNA structures (Figure 2c). However, no extended RNA structure could be identified in the PBS of Boty-II, similar to Grh and Afut1 (Figure 2bFigure2e) (Lin and Levin, 1997).

The polypurine-rich sequence that corresponds to the primer binding site for plus-strand DNA (PPT) synthesis is located immediately upstream of the right LTR, and the sequence of PPT in Boty-II-76, Boty-II-95, Boty-II-103 and Boty-II-141 is 5'-GCCTTGAGCGGGGGGTAC-3'. It is different from Boty, which is 5'AGGCTAAGAAGGGGATAG-3' (Diolez et al. 1995).

\section{Distribution and Phylogenetic analysis of Boty-II LTRs}

To survey the distribution of Boty-II LTRs in B. cinerea B05.10 genome, Boty-II-76- $L$ was extracted and used to

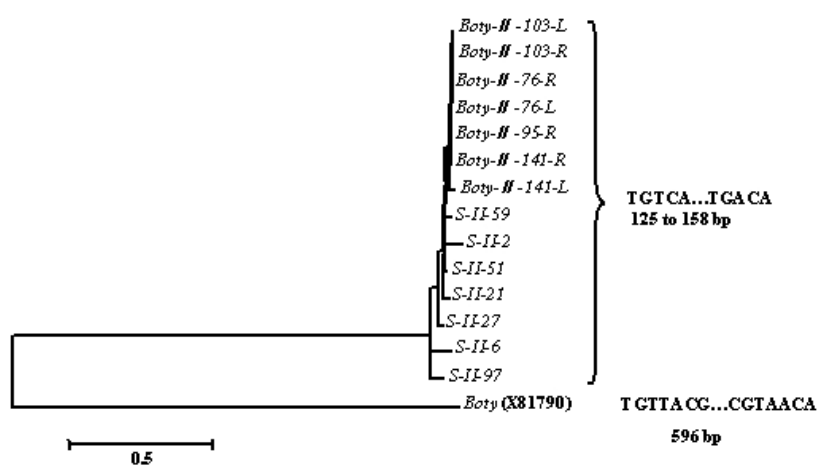

Figure 3. $\mathrm{N}-\mathrm{J}$ tree based on alignment of Boty and Boty-II LTR DNA sequences. 


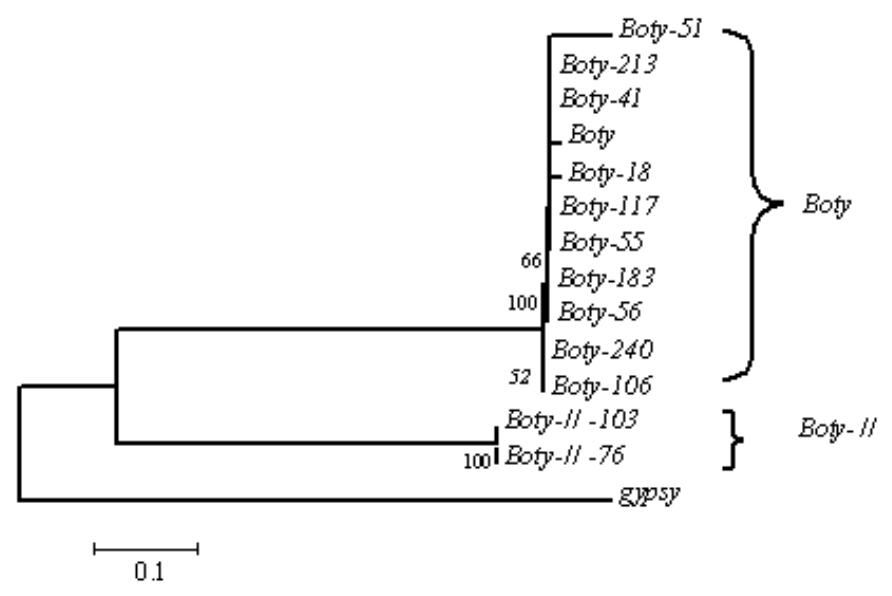

Figure 4. Phylogenetic analysis of LTR retrotransposons in B. cinereabased on alignment of the reverse transcriptase domains. The tree was constructed by the neighbor-joining method (Saitou and Nei, 1987) and rooted using insect Gypsy LTR retrotransposons as outgroups. The number indicates the frequency with which a given branch appeared in 1000 bootstrap replications. Accession numbers for the elements in databases are as follows: Boty, X81791; Boty-18, XP 001557158; Boty-41, XP 001553972; Boty-51, XP 001552885; Boty-55, XP 001552584; Boty-56, XP 001552482; Boty-106, XP 001548698; Boty-117, XP 001548080; Boty-183, XP 001545956; Boty-213, XP 001545506; Boty-240, XP 001545348; Boty-II-76, XP 001550688; Boty-II-103, XP 001552861; gypsy, $\underline{\text { AAA70219. }}$

query the B. cinerea B05.10 genome. Fourteen Boty-II LTRs containing 125 to 158 bp nucleotides and sharing $69.1-100 \%$ identity were identified. They contained short inverted terminal repeats of 5 bp (TGTCA...TGACA) (Boty-II-103-L and Boty-II-103-R contain TGTCA...TGATA; Boty-II-141-Lcontains TGTCA...TAACA; S-II-27 contains TATCA ...TGACA). The genome locations and structural features of Boty-II and Boty-II LTRs are in Table 1. Boty LTR contains 596 bp with a short, inverted 7 bp sequence (TGTTACG...CGTAACA) (Diolez et al. 1995). Phylogenetic analysis revealed Boty and Boty-II LTR form two clades (Figure 3). These results demonstrated that the Boty-II and Boty LTRs are different.

\section{Phylogenetic analysis of LTR-retrotransposons in B. cinerea}

To verify the differences in Boty and Boty-II, we developed a phylogenetic analysis of LTR-retrotransposons in $B$. cinerea. By Blast search, eleven Boty and two Boty-II elements containing the complete RT domains were identified. Amino acid sequences of RT domains were aligned and a N-J tree was constructed based on the alignment by MEGA4.O (Tamura et al. 2007) (Figure 4). This phylogenetic analysis showed that Boty and Boty-II form two monophyletic clades, and validated Boty-II as a novel LTR retrotransposon in B. cinerea.

We concluded that Boty-II is a novel LTR retrotransposon in B. cinerea based on the following evidence: (1) Boty-II contains the internal pol gene flanked by LTRs, which is the hallmark of LTR retrotransposons; (2) Boty-II appears in multiple-copies in the $B$. cinerea B05.10 genome; (3) structural features of Boty and Boty-II, including the short inverted terminal repeats, the length of LTRs and the sequences of PBS and PPT are different; (4) phylogenetic analyses based on DNA sequences of LTRs or amino acid sequences of RT domains revealed that Boty and Boty-II form two monophyletic clades.

Pathogen populations must constantly adapt to changes in their environment to survive. A plant pathogenic fungal population with a high level of genetic variation is likely to adapt more rapidly to fungicides or resistant host plants than populations with little or no genetic variation. Information on the genetic structure of this pathogen population can help us develop effective strategies for the control of disease (Váczy et al. 2007). Genetic variation in $B$. cinerea populations has been studied using resistance to botryicides and a variety of molecular techniques including restriction fragment length polymorphism (RFLP) analysis of PCR-amplified loci, PCR detection of TEs, random amplified polymorphic DNA (RAPD) fingerprinting, amplified fragment length polymorphism (AFLP) analysis, fingerprinting of repetitive sequences by microsatellite primed (MP)-PCR, PCR amplification of microsatellite loci and DNA sequencing of gene regions (Williamson et al. 2007). The DNA polymorphisms of nuclear genes showed that $B$. cinerea isolates consistently clustered in two different clades, Group I and Group II (Albertini et al. 2002; Fournier et al. 2002; Fournier et al. 2003; Fournier et al. 2005). Recently, analysis of microsatellite data showed that $B$. cinerea populations on grapevine and bramble were significantly differentiated, and indicated restricted gene flow, even in sympatry (Fournier and Giraud, 2008).

In this work, we report novel TEs and LTR retrotransposons (Boty-II) in B. cinerea B05.10. This potentially provides a novel molecular marker for the study of genetic variation in $B$. cinerea. Based on the presence or absence of the two known TEs in the genome, $B$. cinerea 
has been grouped into four subpopulations (Giraud et al. 1997; Giraud et al. 1999; Muñoz et al. 2002; Ahmed and Hamada, 2005; Ma and Michailides, 2005; Milicevic et al. 2006). It will be interesting to survey the distribution of Boty-II in other isolates. We presume based on the presence or absence of the three TEs, B. cinerea will potentially be grouped into nine subpopulations.

\section{REFERENCES}

AHMED, Dorsaf Ben and HAMADA, Walid. Genetic diversity of some Tunisian Botrytis cinerea isolates using molecular markers. Phytopathologia Mediterranea, December 2005, vol. 44, no. 3, p. 300-306.

ALBERTINI, Catherine; THEBAUD, Gaël; FOURNIER, Elisabeth and LEROUX, Pierre. Eburicol 14 $\alpha$-demethylase gene (cyp51) polymorphism and speciation in Botrytis cinerea. Mycological Research, October 2002, vol. 106, no. 10, p. 1171-1178.

ALTSCHUL, Stephen F.; MADDEN, Thomas L.; SCHAFFER, Alejandro A.; ZHANG, Hui Jing; ZHANG, Zheng; MILLER, Webb and LIPMAN, David J. Gapped BLAST and PSI-BLAST: a new generation of protein search programs. Nucleic Acids Research, September 1997, vol. 25, no. 17, p. 3389-3402.

BEEVER, Ross E. and WEEDS, Pauline L. Taxonomy and genetic variation of Botrytis and Botryotinia. In: ELAD, Yiga; WILLIAMSON, Brian; TUDZYNSKI, Paul and DELEN, Nafiz. eds. Botrytis: Biology, Pathology and Control. Netherlands, Springer, 2007, p. 29-52.

BILLAULT, Alain; CHOQUER, Mathias; COULOUX, Arnaud; CUOMO, Christina; DECAPRIO, David; DICKMAN, Martin; FILLINGER, Sabine; FOURNIER, Elisabeth; GALAGAN, James; GIRAUD, Corinne; KODIRA, Chinnappa; KOHN, Linda; LEVIS, Caroline; MAUCELI, Evan; POMMIER, Cyril; PRADIER, JeanMarc; QUEVILLON, Emmanuel; ROLLINS, Jeffrey; SÉGURENS, Béatrice; SIMON, Adeline; VIAUD, Muriel; WEISSENBACH, Jean; WINCKER, Patrick and LEBRUN, Marc-Henri. Whole genome sequencing of the fungal plant pathogen Botrytis cinerea: preliminary comparisons with Sclerotinia sclerotiorum genome. In: $I X^{\text {th }}$ International Fungal Biology Conference and $16^{\text {th }}$ New Phytologist Symposium: Impact of genomics on fungal biology. $\left(18^{\text {th }}-20^{\text {th }}\right.$ September, 2006, Nancy, France). Abstracts, 2006. p. 24. Available from Internet: http://www.newphytologist.org/fungal-

genomics/16NPS.pdf.

BUTLER, Margaret; GOODWIN, Timothy; SIMPSON, Matthew; SINGH, Monica and POULTER, Russell. Vertebrate LTR retrotransposons of the Tf1/Sushi group. Journal of Molecular Evolution, March 2001, vol. 52, no. 3, p. 260-274.
DE LIMA FÁVARO, Léia Cecilia; DE ARAÚJO, Welington Luiz; DE AZEVEDO, João Lúcio and PACCOLA-MEIRELLES, Luzia Doretto. The biology and potential for genetic research of transposable elements in filamentous fungi. Genetics and Molecular Biology, December 2005, vol. 28, no. 4, p. 804-813.

DIOLEZ, Annick; MARCHES, Florentina; FORTINI, Dominique and BRYGOO, Yves. Boty, a long-terminalrepeat retroelement in the phytopathogenic fungus Botrytis cinerea. Applied and Environmental Microbiology, January 1995, vol. 61, no. 1, p. 103-108.

ELAD, Yiga; WILLIAMSON, Brian; TUDZYNSKI, Paul and DELEN, Nafiz. Botrytis spp. and diseases they cause in agricultural systems - an introduction. In: ELAD, Yiga; WILLIAMSON, Brian; TUDZYNSKI, Paul and DELEN, Nafiz. eds. Botrytis: Biology, Pathology and Control. Netherlands, Springer, 2007, p. 1-8.

FOURNIER, E.; GIRAUD, T.; LOISEAU, A.; VAUTRIN, D.; ESTOUP, A.; SOLIGNAC, M.; CORNUET, J.M. and BRYGOO, Y. Characterization of nine polymorphic microsatellite loci in the phytopathogenic fungus Botrytis cinerea (Ascomycota). Molecular Ecology Notes, September 2002, vol. 2, no. 3, p. 253-255.

FOURNIER, Elisabeth; LEVIS, Caroline; FORTINI, Dominique; GIRAUD, Tatiana; LEROUX, Pierre and BRYGOO, Yves. Characterization of Bc-hch, the Botrytis cinerea homolog of the neurospora crassa het-c vegetative incompatibility locus, and its use as a population marker. Mycologia, March-April 2003, vol. 95, no. 2, p. 251-261.

FOURNIER, Elisabeth; GIRAUD, Tatiana; ALBERTINI, Catherine and BRYGOO, Yves. Partition of the Botrytis cinerea complex in France using multiple gene genealogies. Mycologia, November-December 2005, vol. 97, no. 6, p. 1251-1267.

FOURNIER, Elisabeth and GIRAUD, Tatiana. Sympatric genetic differentiation of a generalist pathogenic fungus, Botrytis cinerea, on two different host plants, grapevine and bramble. Journal of Evolutionary Biology, January 2008, vol. 21, no. 1, p. 122-132.

Genoscope. Botrytis cinerea, estimated losses for vineyards in France amount to $15-40 \%$ of the harvest, depending on climatic conditions. In: Sequencing projects of Botrytis cinerea [online]. Evry, Genoscope. Last update on 11 January 2008 [cited 30 January 2008]. Available from Internet:

http://www.cns.fr/externe/English/Projets/Projet_LN/organi sme_LN.html

GIRAUD, Tatiana; FORTINI, Dominique; LEVIS, Caroline; LEROUX, Pierre and BRYGOO, Yves. RFLP markers show genetic recombination in Botryotinia fuckeliana (Botrytis cinerea) and transposable elements 
reveal two sympatric species. Molecular Biology and Evolution, November 1997, vol. 14, no. 11, p. 1177-1185.

GIRAUD, T.; FORTINI, D.; LEVIS, C.; LAMARQUE, C.; LEROUX, P.; LOBUGLIO, K. and BRYGOO, Y. Two sibling species of the Botrytis cinerea complex, transposa and vacuma, are found in sympatry on numerous host plants. Phytopathology, October 1999, vol. 89, no. 10, p. 967-973.

KORDIŠ, Dusăn. A genomic perspective on the chromodomain-containing retrotransposons: Chromoviruses. Gene, Mar 2005, vol. 347, no. 2, p. 161173.

KRETSCHMER, M. and HAHN, M. Fungicide resistance and genetic diversity of Botrytis cinerea isolates from a vineyard in Germany. Journal of Plant Diseases and Protection, October 2008, vol. 115, no. 5, p. 214-219.

LEVIN, Henry L. A novel mechanism of self-primed reverse transcription defines a new family of retroelements. Molecular and Cellular Biology, June 1995, vol. 15, no. 6, p. 3310-3317.

LEVIN, Henry L. An unusual mechanism of self-primed reverse transcription requires the RNase $\mathrm{H}$ domain of reverse transcriptase to cleave an RNA duplex. Molecular and Cellular Biology, October 1996, vol. 16, no. 10, p. 5645-5654.

LEVIS, Caroline; FORTINI, Dominique and BRYGOO, Yves. Flipper, a mobile Fot1-like transposable element in Botrytis cinerea. Molecular Genetics and Genomics, May 1997, vol. 254, no. 6, p. 674-680.

LIN, Jia Hwei and LEVIN, Henry L. Self-primed reverse transcription is a mechanism shared by several LTRcontaining retrotransposons. RNA, September 1997, vol. 3, no. 9, p. 952-953.

LOWE, Todd M. and EDDY, Sean R. tRNAscan-SE: a program for improved detection of transfer RNA genes in genomic sequence. Nucleic Acids Research, March 1997, vol. 25, no. 5, p. 955-964.

MA, Zhonghua and MICHAILIDES, Themis J. Genetic structure of Botrytis cinerea populations from different host plants in California. Plant Disease, October 2005, vol. 89, no. 10 , p. $1083-1089$.

MILICEVIC, T.; TOPOLOVEC, P.S.; CVJETKOVIC, B.; IVIC, D. and DURALIJA, B. Sympatric subpopulations of Botrytis cinerea on strawberries based on the content of transposable elements and their connection with resistance to botryticides. Acta Horticulturae, May 2006, vol. 708, p. 115-118.

MUÑOZ, Gastón; HINRICHSEN, Patricio; BRYGOO, Yves and GRIAUD, Tatiana. Genetic characterization of
Botrytis cinerea populations in Chile. Mycological Research, May 2002, vol. 106, no. 5, p. 594-601.

SAITOU, Naruya and NEI, Masatoshi. The neighborjoining method: a new method for reconstructing phylogenetic trees. Molecular Biology and Evolution, July 1987, vol. 4, no. 4, p. 406-425.

TAMURA, Koichiro; DUDLEY, Joel; NEI, Masatoshi and KUMAR, Sudhir. MEGA4: molecular evolutionary genetics analysis (MEGA) software version 4.0. Molecular Biology and Evolution, August 2007, vol. 24, no. 8, p. 1596-1599.

TATUSOVA, Tatiana A. and MADDEN, Thomas L. Blast 2 sequences, a new tool for comparing protein and nucleotide sequences. FEMS Microbiology Letters, May 1999, vol. 174, no. 2, p. 247-250.

VÁCZY, Kálmán Z.; KARAFFA, Levente; GÁL, Lajos; KÖVICS, György; SÁNDOR, Erzsébet. Genetic characterisation of Botrytis cinerea populations in the eger wine district. In: $30^{\text {th }}$ World Congress of Vine and Wine. $\left(10^{\text {th }}-16^{\text {th }}\right.$ June, 2007, Budapest, Hungary). [cited 6 January 2008]. Available from Internet: http://www.oiv2007.hu/documents/viniculture/402_vaczy_ pros.pdf.

WICKER, Thomas; SABOT, François; HUA-VAN, Aurélie; BENNETZEN, Jeffrey L.; CAPY, Pierre; CHALHOUB, Boulos; FLAVELL, Andrew; LEROY, Philippe; MORGANTE, Michele; PANAUD, Olivier; PAUX, Etienne; SANMIGUEL, Phillip and SCHULMAN, Alan H. A unified classification system for eukaryotic transposable elements. Nature Reviews Genetics, December 2007, vol. 8, no. 2, p. 973-982.

WILLIAMSON, Brian; TUDZYNSKI, Bettina; TUDZYNSKI, Paul and VAN KAN, Jan A.L. Pathogen profile - Botrytis cinerea: the cause of grey mould disease. Molecular Plant Pathology, September 2007, vol. 8, p. 561-580. 


\section{APPENDIX \\ TABLE}

Table 1. Summary of Boty-II elementsin the B. cinerea B05.10 genome.

\begin{tabular}{|c|c|c|c|c|}
\hline $\begin{array}{l}\text { Names of Boty-II } \\
\text { (Genome location) }\end{array}$ & $\begin{array}{l}\text { Names and Short inverted } \\
\text { terminal repeats of LTR } \\
\text { (Genome location) }\end{array}$ & $\begin{array}{c}\text { Putative internal } \\
\text { protein } \\
\text { (Genbank } \\
\text { Accession } \\
\text { numbers; } \\
\text { Genome } \\
\text { location) }\end{array}$ & $\begin{array}{l}\text { Putative conserved } \\
\text { domains of internal } \\
\text { protein }\end{array}$ & $\begin{array}{l}\text { Target site } \\
\text { duplications }\end{array}$ \\
\hline & $\begin{array}{l}\text { S-II-2 } \\
\text { TGTCA...TGACA } \\
\text { (Supercontig 2: } \\
429990-430147+\text { ) }\end{array}$ & & & ACTA \\
\hline & $\begin{array}{l}\text { S-II- } 6 \\
\text { TGTCA...TGACA } \\
\text { (Supercontig 6: } \\
34252-34400+\text { ) }\end{array}$ & & & \\
\hline & $\begin{array}{l}\text { S-II-21 } \\
\text { TGTCA...TGACA } \\
\text { (Supercontig 21: 21: } \\
668-816+\text { ) }\end{array}$ & & & GAAAA \\
\hline & $\begin{array}{l}\text { S-II-27 } \\
\text { TATCA...TGACA } \\
\text { (Supercontig } 27 \text { : } \\
\text { 18469-18621 +) }\end{array}$ & & & \\
\hline & $\begin{array}{l}\text { S -II-51 } \\
\text { TGTCA...TGACA } \\
\text { (Supercontig 51 : } \\
\text { 163167-163291 +) }\end{array}$ & & & ATA \\
\hline & $\begin{array}{l}\text { S-II- } 59 \\
\text { TGTCA...TGACA } \\
\text { (Supercontig 59: } \\
\text { 225815-225963+) }\end{array}$ & & & TTATA \\
\hline $\begin{array}{l}\text { Boty-II-76 } \\
\text { (Supercontig 76: } \\
\text { 146126-152564 +) }\end{array}$ & $\begin{array}{l}\text { Boty-II-76- L } \\
\text { TGTCA...TGACA } \\
\text { (Supercontig 76: } \\
\text { 146126-146274 +) }\end{array}$ & $\begin{array}{l}\text { hypothetical protein } \\
\text { BC1G_11096 } \\
\text { (XP_001550688; } \\
\text { Supercontig 76: } \\
\text { 146446-152348+) }\end{array}$ & RT, INT & ACCAT \\
\hline & $\begin{array}{l}\text { Boty-II-76- } R \\
\text { TGTCA...TGACA } \\
\text { (Supercontig 76: } \\
\text { 152416-152564 +) }\end{array}$ & & & \\
\hline $\begin{array}{l}\text { Boty-II-95 } \\
\text { (Supercontig 95: } \\
\text { 159369-N*-) }\end{array}$ & $\begin{array}{l}\text { Boty-II-95-R } \\
\text { TGTCA...TGACA } \\
\text { (Supercontig 95 : } \\
\text { 159369-159517 -) }\end{array}$ & & & \\
\hline
\end{tabular}




\begin{tabular}{|c|c|c|c|c|}
\hline & $\begin{array}{l}\text { S-II-97 } \\
\text { TGTCA...TGACA } \\
\text { (Supercontig } 97: \\
\text { 149630-149778 -) }\end{array}$ & & & CTACA \\
\hline & $\begin{array}{l}\text { Boty-II-103-R } \\
\text { TGTCA...TGATA } \\
\text { (Supercontig 103: } \\
\text { 52511-52659-) }\end{array}$ & & & \\
\hline \multirow[t]{2}{*}{$\begin{array}{l}\text { Boty-II-141 (Supercontig } \\
\text { 141: } 1246-6523-\text { ) }\end{array}$} & $\begin{array}{l}\text { Boty-II-141-R } \\
\text { TGTCA...TGACA } \\
\text { (Supercontig 141: } \\
\text { 193-337 -) }\end{array}$ & $\begin{array}{l}\text { hypothetical protein } \\
\text { BC1G_14556 } \\
\text { (Supercontig 141: } \\
\text { XP_001547118; } \\
\text { Supercontig 141: 623- } \\
\text { 2824) }\end{array}$ & INT & \\
\hline & $\begin{array}{l}\text { Boty-II-141-L } \\
\text { TGTCA...TGACA } \\
\text { (Supercontig 141: } \\
6375-6523-\text { ) }\end{array}$ & & & \\
\hline
\end{tabular}

INT indicates DDE integrase domain; RT indicates reverse transcriptase domain; $N$ indicates there are gaps in the genome. 